\title{
PONDEROSA PINE AND SUGAR PINE PLYWOOD
}

\section{COMMERCIAL STANDARD CS157-49}

Effective Date for New Production From March 25, 1949

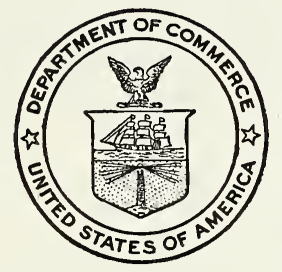

A RECORDED VOLUNTARY STANDARD

OF THE TRADE

UNITED STATES DEPARTMENT OF COMMERCE CHARLES SAWYER, Secretary 


\section{COMMODITY STANDARDS}

Simplified Practice Recommendations and Commercial Standards are developed by manufacturers, distributors, and users in cooperation with the Commodity Standards Division of the National Bureau of Standards. The purpose of Simplified Practice Recommendations is to eliminate avoidable waste through the establishment of standards of practice for stock sizes and varieties of specific commodities that currently are in general production and demand. The purpose of Commercial Standards is to establish standard methods of test, rating, certification, and labeling of commodities, and to provide uniform bases for fair competition.

The adoption and use of a Simplified Practice Recommendation or Commercial Standard is voluntary. However, when reference to a Commercial Standard is made in contracts, labels, invoices, or advertising literature, the provisions of the standard are enforceable through usual legal channels as a part of the sales contract.

A Simplified Practice Recommendation or Commercial Standard originates with the proponent industry. The sponsors may be manufacturers, distributors, or users of the specific product. One of these three elements of industry submits to the Commodity Standards Division the necessary data to be used as the basis for developing a standard of practice. The Division, by means of assembled conferences or letter referenda, or both, assists the sponsor group in arriving at a tentative standard of practice and thereafter refers it to the other elements of the same industry for approval or for constructive criticism that will be helpful in making any necessary adjustments. The regular procedure of the Division assures continuous servicing of each effective Simplified Practice Recommendation and Commercial Standard, through review and revision, whenever, in the opinion of the industry, changing conditions warrant such action. Simplified Practice Recommendations and Commercial Standards are printed and made available by the Department of Commerce, through the Government Printing Office.

\section{COMMERCIAL STANDARD FOR PONDEROSA PINE AND SUGAR PINE PLYWOOD}

On August 23, 1948, a recommended commercial standard for ponderosa pine and sugar pine plywood, proposed by representative manufacturers of these products, and adjusted in accordance with suggestions from the industry, was circulated to manufacturers, distributors, and consumer organizations for consideration and approval. Those concerned have since accepted and approved the standard as set forth herein.

Project Manager: J. W. Medley, Commodity Standards Division, National Bureau of Standards.

Technical Adviser: V. B. Phelan, Building Technology Division, National Bureau of Standards. 
for

\section{PONDEROSA PINE AND SUGAR PINE PLYWOOD}

\section{PURPOSE}

1. Because of the increasing production of ponderosa pine and sugar pine plywood, the standard grading rules set forth herein are offered as a universal basis of understanding in the industry. General adoption and use of this standard will facilitate procurement of the proper grade of material for its varied uses and provide a better understanding between buyer and seller.

\section{SCOPE}

2. This standard covers requirements for eight grades of special moisture-resistant interior type ponderosa pine and sugar pine plywood. In addition there are included test requirements, standard sizes, size tolerances, inspection rules, labeling, and nomenclature and definitions.

\section{GENERAL REQUIREMENTS}

3. All ponderosa pine and sugar pine plywood sold as of commercia standard quality shall meet the following general requirements.

4. Workmanship.-Ponderosa pine and sugar pine plywood shall be well manufactured and free from blisters, laps, or other defects not specifically permitted in the rules for the various grades. Unless otherwise specified, it shall be smoothly sanded on two sides. When rough or unsanded plywood is specified, it may have paper tape on either face or back, or both. Veneers shall be tight, smoothly cut, and of uniform thickness.

5. Bonding.-The entire area of each contacting surface of the plywood shall be bonded in an approved manner with a moistureresistant adhesive that will meet the test requirements as given in paragraphs 16 and 17.

6. Core and crossbands.-Unless otherwise specified, the cores and crossbands of all panels shall be of one or more pieces of veneer, and may contain knots, plugs, and other defects that do not impair a smooth surface under the face veneer.

\section{DETAIL REQUIREMENTS}

7. Ponderosa pine and sugar pine plywood shall be graded according to both sides of the piece into the standard grades described in paragraphs 8 to 15 . The grade descriptions set forth the minimum re- 
quirements, and, therefore, the majority of panels in any shipment will exceed the specifications given.

8. Good 2 Sides (G2S).-Each face shall be of a single piece of firm, smoothly cut veneer, except that up to 25 percent of the panels may contain one face of two pieces, on widths of 24 in. to 36 in., and of two or three pieces, on widths over 36 in. to 48 in., that are reasonably matched for grain and color, and well joined. Faces shall be free from knots, splits, checks, pitch pockets, and other open defects. The faces shall be without blue stain. Slight discolorations, heart, and sap streaks shall be admitted. Tightly closed end checks, shims not more than $3 / 16$ in. wide that occur at ends of panels, and inconspicuous well-matched small patches shall be admitted. This grade is required for uses where a light stain finish, natural finish, or enamel finish is desired. Construction shall be of pine veneer throughout.

9. Good 1 Side $(G 1 S)$.- The face shall be equal to that described under Good 2 Sides grade (par. 8) and the back shall be equal to the Sound 2 Sides grade (par. 10). Construction shall be of pine veneer throughout.

10. Sound 2 Sides (So2S).-Each face shall be of one or more pieces of firm smoothly cut veneer. When of more than one piece the pieces shall be well joined. The faces shall be free from knots, splits, checks, pitch pockets, and other open defects. Streaks, discolorations, black pinhead specks, shims, and neatly made patches shall be admitted. This grade shall present a smooth surface suitable for painting. Construction shall be of pine veneer throughout.

11. Sound 1 Side-Solid 1 Side (So1S-Sld1S). - The face shall be of the same grade as described for Sound 2 Sides (par. 10). The back shall be of the same grade as described for Solid 2 Sides (par. 13). Construction shall be of pine veneer throughout.

12. Sound 1 Side $\left(S_{01 S}\right)$. - The face shall be equal to that described under Sound 2 Sides grade (par. 10). The back shall be unplugged and unpatched and may contain knots, knotholes, pitch pockets, splits, and other defects in number and size that will not seriously affect the strength or serviceability of the panel. Construction shall be of pine veneer throughout.

13. Solid 2 Sides $($ Sld2S).-Each face shall be of the same grade. The faces shall present a solid surface free from open defects but in addition to characteristics admitted in Sound grade veneer (par. 10), they shall also admit neatly made circular plugs as well as synthetic plugs that present a smooth hard surface, knots if both sound and tight, slightly rough but not torn grain, and other minor sanding and patching defects. The grade shall be paintable. Intermixing of species is permitted in inner plies.

14. Solid 1 Side (Sld1S).-The face shall be of the same grade as that described for Solid 2 Sides (par. 13). The back shall be unplugged and unpatched and may contain knots, knotholes, pitch pockets, splits, and other defects in number and size that will not seriously affect the strength or serviceability of the panel. Intermixing of species is permitted in inner plies.

15. Sheathing (Shtg).-This is an unsanded plywood panel. The face shall permit the following: (a) not more than 10 knotholes, none of which shall exceed 1 1/2 in., (b) no group of knotholes within any 12-in.-diameter circle shall have an aggregate dimension of more than 
3 in., (c) no splits wider than $1 / 4$ in., nor open pitch pockets more than 1 in. wide. There may be any number of patches and plugs in the face. No belt sanding is permissible. The back shall be unplugged and unpatched and may contain knots, knotholes, pitch pockets, splits, and other defects in number and size that will not seriously affect the strength or serviceability of the panel. Intermixing of species is permitted in inner plies.

\section{TEST}

16. Sampling.-Pieces for testing shall be taken from 1 percent of the panels in any shipment, but not less than 5 nor more than 10 panels shall be selected. From each panel selected a test piece shall be cut from each end approximately at midwidth of the panel, and from each edge approximately at midlength of the panel, and a fifth piece shall be cut from somewhere near the middle or center of the panel.

17. Delamination test.-One test specimen 6 in. by 6 in. shall be taken from each test piece. The specimens shall be submerged in water at room temperature for a period of 4 hours, and then dried at a temperature not exceeding $100^{\circ} \mathrm{F}$. for a period of 20 hours. This cycle shall be repeated nine additional times, after which the test specimens must not show a delamination between any two layers of veneer totaling more than 2 in. measured parallel to the edge.

\section{STANDARD SIZES}

18. Ponderosa pine and sugar pine plywood is made in the standard sizes given in table 1 .

TABLE 1.-Standard sizes of ponderosa pine and sugar pine plywood

\begin{tabular}{|c|c|c|c|}
\hline Grades & Width & Length & Thickness \\
\hline $\begin{array}{l}\text { (G2S) } \\
\text { (G1S) } \\
\text { (So1S-Sid1S) } \\
\text { (So1S) } \\
\text { (Sld2S) } \\
\text { (Sld1S) }\end{array}$ & $\begin{array}{c}\text { Inches } \\
12,14,16,18,20,22,24,26,28 \\
30,32,34,36,38,40,42,44 \\
46,48\end{array}$ & 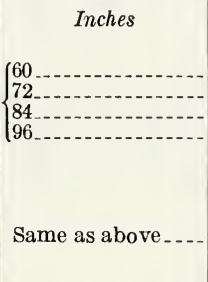 & $\begin{array}{c}\text { Inch } \\
\left\{\begin{array}{l}1 / 4 \text { (3-ply; sanded } 2 \text { sides). } \\
3 / 8 \text { (3-ply; sanded 2 sides). } \\
1 / 2 \text { (5-ply; sanded 2 sides). } \\
5 / 8 \text { (5-ply; sanded 2 sides). } \\
3 / 4 \text { (5-ply; sanded 2 sides). } \\
1 \text { (7-ply; sanded 2 sides). }\end{array}\right. \\
\left\{\begin{array}{l}5 / 16 \text { (3-ply; unsanded). } \\
3 / 8 \text { (3-ply; unsanded). } \\
1 / 2 \text { (5-ply; unsanded). } \\
5 / 8 \text { (5-ply; unsanded). }\end{array}\right.\end{array}$ \\
\hline
\end{tabular}

19. Width always refers to the distance across the grain of the face plies; length refers to the distance along the grain of the face plies. When ordering, width should always be specified first.

\section{SIZE TOLERANCES}

20. A tolerance of $1 / 64$ in. over or under the specified thickness shall be allowed on sanded panels, and a tolerance of $1 / 32$ in. on unsanded panels.

21. A tolerance of $1 / 16$ in. over or under the specified length and/or width shall be allowed, but all panels shall be square within $1 / 8$ in. 


\section{MEASUREMENT}

22. The footage of panels is figured on a full-inch basis. When panels are cut to a special size and the width and/or length are in fractions of an inch, these fractional measurements shall be counted as of the next full inch.

\section{INSPECTION}

23. All plywood guaranteed to conform to the commercial standard grading rules is sold subject to inspection in the white only. All complaints regarding the quality of any shipment must be made within 15 days from receipt thereof.

24 . If the grade of any plywood shipment is in dispute and a reinspection is demanded, the cost of such reinspection shall be borne by the seller and the shipment settled for on the basis of the reinspection report if the shipment is more than 5 percent below grade, or if it contains more than 1 percent of mismanufactured panels containing defects such as short core, lapped core, blisters, delamination, etc., which render the panel unfit for normal use. The buyer need not accept such defective panels shipped as any standard grade listed in this commercial standard.

25 . If reinspection establishes the shipment to be 5 percent or less below grade, and to contain 1 percent or less of mismanufactured panels, the buyer shall pay the cost of reinspection and shall pay for the shipment as invoiced.

\section{LABELING}

26. In order that the purchaser may be assured of obtaining ponderosa pine plywood or sugar pine plywood conforming to the requirements of this standard, it is recommended that shipments complying therewith be accompanied by a statement containing the following wording:

This shipment of ponderosa pine or sugar pine plywood complies with all the requirements of Commercial Standard CS157-49, as developed by the trade, under the procedure of the National Bureau of Standards, and issued by the U. S. Department of Commerce.

(Name of manufacturer)

\section{NOMENCLATURE AND DEFINITIONS}

27. The terms used in this standard are defined as follows: Back. -The side reverse to the face of the panel.

Borer holes.-Voids made by wood-boring insects or worms. Centers.-See Cores.

Checks. - Small splits running parallel to the grain of the wood caused chiefly by strains produced in seasoning.

Cores.-Cores, or centers, are the innermost layer in plywood construction. 
Crossbanding.-Veneer used in the construction of plywood with five or more plies. In five-ply construction it is placed at right angles between the core and faces.

Defects, open.-Checks, splits, open joints, cracks, loose knots, and other defects interrupting the smooth continuity of the panel surface.

Face.-The better side of a panel in any grade calling for a face and a back; also, either side of a panel where the grading rules draw no distinction between faces.

Heartwood.- The darker-colored wood occurring in the inner portion of the tree, sometimes referred to as "heart."

Knot.-Cross section of a branch or limb whose grain usually runs at right angles to that of the piece in which it is found.

Knotholes.-Voids produced by the dropping of knots from the wood in which they were originally embedded.

Lap.-A condition where the veneers used are so misplaced that one piece overlaps the other instead of making a smooth butt joint.

Patches.-Insertions of sound wood glued and placed into panels from which defective portions have been removed.

Small patch.-A patch not larger than $1 / 2$ in. by 3 in.

Pitch pocket.-A well-defined opening between rings of annual growth, usually containing, or which has contained, more or less pitch, either solid or liquid.

Pitch streak.-A well-defined accumulation of pitch in a more or less regular streak.

Sapwood.-The lighter-colored wood occurring in the outer portion of the tree, sometimes referred to as "sap."

Shim.-A long, narrow patch.

Streak.-Discoloration caused by an accumulation of resinous substance or chemical change within the wood.

\section{EFFECTIVE DATE}

28. Having been passed through the regular procedure of the Commodity Standards Division, and approved by the acceptors hereinafter listed, this commercial standard was issued by the United States Department of Commerce, effective from March 25, 1949.

Edwin W. Ely, Chief, Commodity Standards Division.

\section{HISTORY OF THE PROJECT}

Increasing demand for ponderosa pine and sugar pine plywood prompted leading manufacturers, on November 6, 1947, to request the cooperation of the National Bureau of Standards in the establishment of a commercial standard as a means of providing a nationally recognized specification for these products. Complying with this request, the Bureau's Commodity Standards Division circulated the manufacturers' preliminary draft to all interests, including representative manufacturers, distributors, and consumer organizations, for advance review and comment. 
On August 23, 1948, the recommended standard, adjusted in accordance with the constructive suggestions received, was circulated to the industry and trade for consideration and acceptance.

The satisfactory results of this circularization warranted promulgation and publication of the proposal as Commercial Standard CS157-49, Ponderosa Pine and Sugar Pine Plywood, and on February 24,1949 , the effective date of the standard, March 25, 1949, was announced.

\section{STANDING COMMITTEE}

The following individuals comprise the membership of the standing committee, which is to review, prior to circulation for acceptance, revisions proposed to keep the standard abreast of progress. Comment concerning the standard and suggestions for revisions may be addressed to any member of the committee or to the Commodity Standards Division, National Bureau of Standards, which acts as secretary for the committee.

Fay L. Foval (chairman), The Long-Bell Lumber Co., Longview, Wash.

A. J. Honzel, Kalpine Plywood Co., Division of Plywood, Inc., P. O. Box 109, Klamath Falls, Oreg.

D. G. Birmingham, Shasta Plywood, Inc., P. O. Box 1688, Redding, Calif.

Floyd Hart, Timber Products Co., Medford, Oreg.

C. W. Ocker, Curtis Co., Inc., Clinton, Iowa (representing National Door Manufacturers Association)

P. S. Hill, Harbor Plywood Corp., 1444 W. Cermak Road, Chicago 8, Ill. (representing Woodwork Jobbers Service Bureau).

Harry H. Steidle, Prefabricated Home Manufacturers' Institute, 908 Twentieth Street NW., Washington 6, D. C.

Gerald L. Palmer, American Specification Institute, 134 N. La Salle Street, Chicago 2, Ill.

B. E. BAвBITT, National Plywood Distributors Association, 20 North Wacker Drive, Chicago 6, Ill.

Norman F. Stambaugh, Rhodes Building, 78 Marietta Street, Atlanta 1, Ga (representing the American Institute of Architects). 


\section{ACCEPTANCE OF COMMERCIAL STANDARD}

If acceptance has not previously been filed, this sheet properly filled in, signed, and returned will provide for the recording of your organization as an acceptor of this commercial standard.

Date

Commodity Standards Division,

National Bureau of Standards, Washington 25, D. C.

Gentlemen:

We believe that the Commercial Standard CS157-49 constitutes a useful standard of practice, and we individually plan to utilize it as far as practicable in the production $^{1} \quad$ distribution $^{1} \quad$ purchase $^{1} \quad$ testing $^{1}$ of ponderosa pine and sugar pine plywood.

We reserve the right to depart from it as we deem advisable.

We understand, of course, that only those articles which actually comply with the standard in all respects can be identified or labeled as conforming thereto.

Signature of authorized officer

(In ink)

(Kindly typewrite or print the following lines)

Name and title of above officer

Organization

(Fill in exactly as it should be listed)

Street address.

City, zone, and State

1 Underscore which one. Please see that separate acceptances are filed for all subsidiary companies and affiliates which should be listed separately as acceptors. In the case of related interests, trade associations, trade papers, etc., desiring to record their general support, the words "General Support" should be added after the signature. 


\section{TO THE ACCEPTOR}

The following statements answer the usual questions arising in connection with the acceptance and its significance:

1. Enforcement.-Commercial standards are commodity specifications voluntarily established by mutual consent of those concerned. They present a common basis of understanding between the producer, distributor, and consumer and should not be confused with any plan of governmental regulation or control. The United States Department of Commerce has no regulatory power in the enforcement of their provisions, but since they represent the will of the interested groups as a whole, their provisions through usage soon become established as trade customs, and are made effective through incorporation into sales contracts by means of labels, invoices, and the like.

2. The acceptor's responsibility.-The purpose of commercial standards is to establish for specific commodities, nationally recognized grades or consumer criteria, and the benefits therefrom will be measurable in direct proportion to their general recognition and actual use. Instances will occur when it may be necessary to deviate from the standard and the signing of an acceptance does not preclude such departures; however, such signature indicates an intention to follow the commercial standard where practicable, in the production, distribution, or consumption of the article in question.

3. The Department's responsibility.-The major function performed by the Department of Commerce in the voluntary establishment of commercial standards on a Nation-wide basis is fourfold: First, to act as an unbiased coordinator to bring all interested parties together for the mutually satisfactory adjustment of trade standards; second, to supply such assistance and advice as past experience with similar programs may suggest; third, to canvass and record the extent of acceptance and adherence to the standard on the part of producers, distributors, and users; and fourth, after acceptance, to publish and promulgate the standard for the information and guidance of buyers and sellers of the commodity.

4. Announcement and promulgation.-When the standard has been endorsed by a satisfactory majority of production or consumption in the absence of active valid opposition, the success of the project is announced. If, however, in the opinion of the standing committee or the Department of Commerce, the support of any standard is inadequate, the right is reserved to withhold promulgation and publication. 


\section{AGCEPTORS}

The organizations listed below have individually accepted this standard for use as far as practicable in the production, distribution, testing, or purchase of ponderosa pine and sugar pine plywood. In accepting the standard they reserved the right to depart therefrom as they individually deem advisable. It is expected that products which actually comply with the requirements of this standard in all respects will be regularly identified or labeled as conforming thereto, and that purchasers will require such specific evidence of conformity.

\section{ASSOCIATIONS}

(General Support)

American Specification Institute, Chicago, Ill.

Building Officials Conference of America, Washington, D. C.

Carolina Lumber \& Building Supply Association, Charlotte, N.C.

Greater New York Lumber Industries, Inc., New York, N. Y.

Hardwood Plywood Institute, Chicago, Ill.

Michigan Retail Lumber Dealers Association, Länsing, Mich.

Mississippi Retail Lumber Dealers Association, Inc., Jackson, Miss.

National Hardwood Lumber Association, Chicago, Ill.

National Plywood Distributors Association, Chicago, Ill.

Prefabricated Home Manufacturers' Institute, Washington, D. C.

Southern California Retail Lumber Association, Los Angeles, Calif.

Southern Hardwood Producers, Inc., Memphis, Tenn.

Veneer Association, The, Chicago, Ill.

Woodwork Jobbers Service Bureau, Chicago, Ill.

\section{FIRMS AND OTHER INTERESTS}

Aberdeen Plywood Corp., Aberdeen, Wash. Acme Door Co., The, Hoquiam, Wash.

Adams, Franklin O., Tampa, Fla.

A etna Plywood \& Veneer Co., Chicago, Ill.

Albany Plywood Co., Inc., Albany, N. Y.

Algoma Plywood \& Veneer Co., Algoma, Wis.

American Plywood Corp., New London, W is.

Andrews, C. E., Lumber Co., New Bethlehem, $\mathrm{Pa}$

Andrews, Jones, Biscoe \& Goodell, Boston, Mass.

(General support.)

Atlantic Plywood Co., Inc., New York, N. Y.
Bakelite Corp., New York, N. Y., and Bloomfield, N. J.

Baldridge, J. C., Lumber Co., Albuquerque, N. Mex.

Baris, J. C., Lumber Co., New York, N. Y.

Baxter, C. B., \& Co., Kansas City, Mo.

Becker \& Danowitz Co., Inc., Maspeth, N. Y.

Belli, Edo J., Chicago, IIll.

Belli Co., Trenton, N. J.

Bennison, Harvey C., Co., Kansas City, Mo.

Besch, Carl, Co., The, New York, N. Y.

Bestline Corp., Olympia, Wash.

Binswanger \& Co., Inc., Richmond, Va.

Blackburn, Robert, Inc., Milwaukee, Wis.

Boeing Airplane Co., Wichita Division, Wichita, Kans.

Borcherding, W. C., Co., Indianapolis, Ind.

Borden Co., The, Chemical Division, Seattle, Wash.

Bosman \& Casson, Inc., Harrison, N. J.

Botsford Lumber Co., Winona, Minn.

Bovard, William R., Kansas City, Mo. (General support.)

Bratton-Longwell Co., Memphis, Tenn.

Brazer, Clarence W., New York, N. Y.
Bruett, T. A., Lumber, Inc., Milwaukee, W is

Brust \& Brust, Milwaukee, Wis.

Bryan-Beck, Staunton, Va.

Buckley, F.S., Door Co., San Francisco, Calif.

Buell \& Co., Dallas, Tex.

Buffalo, City of, Architectural Service, Buildings Division, Department of Public Works, Buffalo, N. Y.

Buffalo Plywood Corp., Buffalo, N. Y.

Buffelin Manufacturing Co., Tacoma, Wash., and Fort Worth, Tex.

California Builders Supply Co., Oakland, Sacra. mento, and Fresno, Calif.

California Door Co., The, Los Angeles, Calif.

California Panel \& Veneer Co., Los Angeles, Calif.

Cameron, Wm., \& Co., Inc., Waco, Tex.

Cameron Lumber Co., Inc., New Windsor, Newburgh, N. Y.

Camlet, J. Thomas, Passaic, N. J.

Camp, E. W., Plywood Co., Inc., Indianapolis, Ind. Cannon \& Mullen, Salt Lake City, Utah.

Cellar Lumber Co., Westerville, Ohio.

Central Building Supply, Baltimore, Md.

Central Wholesale Co., Inc., Shreveport, La.

Charlottesville Lumber Co., Charlottesville, Va.

Chrysler Corp., Detroit, Mich.

Cincinnati Butchers' Supply Co., The, Cincinnati, Ohio.

Cincinnati, City of, Department of Purchasing, Cincinnati, Ohio.

Clark, Carl W., Syracuse, N. Y.

Coale's Distributing Lumber Co., Philadelphia, Pa . Coffin, Ralph V., Seattle, Wash.

Cole Manufacturing Co., Memphis, Tenn.

Combs Lumber Co., Inc., Lexington, $\mathrm{Ky}$.

Conerete Grid Forms, Berkeley, Calif.

Conrad \& Cummings, Binghamton, N. Y.

Cottonwood Lumber Co., Cottonwood, Ariz.

Cresmer Manufacturing Co., Riverside, Calif.

Crompton \& Knowles Loom Works, Worcester Mass. Cross, Austin \& Ireland Lumber Co., Brooklyn,

Crowell \& Lancaster, Bangor, Maine.

Curran Bros., Pomona, Calif.

Curtis Cos., Inc., Clinton, Iowa

Cuyahoga Lumber Co., The, Cleveland, Ohio.

Dakota Sash \& Door Co., Aberdeen, S. Dak.

Darby, Bogner \& Associates, Milwaukee, Wis.

Davidson Sash \& Door Co., Inc., Lake Charles, La.

Delmarva Sash \& Door Co., Philadelphia, Pa.

Dobbs, A. A., Manufacturing Co., Orlando, Fla.

Donovan, John J., Berkeley, Calif.

Downes Lumber Co., Boston, Mass.

Durez Plastics \& C hemicals, Inc., Ncrth Tonawanda, N. Y.

East Bay Refrigerator \& Fixture Co., Oakland, Calif.

East Coast Lumber \& Supply Co., Millwork Division, Fort Pierce, Fla.

Eastern Plywood \& Door Co., Inc., Jamestown, N. Y.

Elizabeth Lumber Co., Elizabeth, N. J.

Empire Sash \& Door Co., Ltd., Winnipeg, Manitoba, Canada.

Ester Lumber Co., Birmingham, A la. 
Fairchild Aircraft Corp., Division of Fairchild Engine \& Airplane Corp., Hagerstown, Md.

Farley-Loetscher Co., Sioux Falls, S. Dak.

Farley \& Loetscher Manufacturing Co., Dubuque, Iowa.

Fischer, Charles F., \& Co., Inc., New York, N. Y.

Fitz Gibbon, T. David, Norfolk, Va.

Fitzpatrick, J. J., Lumber Co., Inc., Madison, Wis.

Flannagan, Eric G., Henderson, N.C

Florence Manufacturing Co., Inglewood, Calif.

Ford, Ivon R., Inc., MeDonough, N. Y.

Forest Products Corp., Fort Lauderdale, Fla.

Forest Products Laboratories of Canada, Ottawa, Ontario, Canada.

Fort Wayne Builders Supply Co., Fort Wayne, Ind. Frederick Bros., Inc., Pottstown, Pa.

Frost Hardwood Lumber Co., San Diego, Calif.

Fruit Growers Supply Co., Westwood, Calif.

Fry-Fulton Lumber Co., St. Louis, Mo.

Fuller, W. P., \& Co., Sacramento, Calif., and Spc-

kane, Wash.

Gaines Hardwood Lumber Co., St. Louis, Mo.

Garratt \& Co., Wayne, Pa.

General Box Ćo., Chicago, Ill

General Electric Co., Schenectady, N. Y.

General Millwork Corp., Utica, N. Y

Georgia-Pacific Plywood \& Lumber Co., Augusta, Ga.

Godfrey Lumber Co., Boston, Mass.

Grand Rapids Store Equipment Co., Grand Rapids, Mich.

Great Lakes Sash \& Door Co., The, Cleveland, Ohio.

Greene \& Wood, Inc., New Bedford, Mass.

Groffmann, Louis C., St. Louis, Mo.

Gulf States Plywood Co., New Orleans, La.

Hager \& Cove Lumber Co., Lansing, Mich.

Hahn, Stanley W., Chicago, Ill

Haralson \& Mott, Fort Smith, Ark.

Harbor Plywood Corp., Hoquiam, Wash.

Harbor Sales Co., Inc., The, Baltimore, Md.

Hartung, F. L., Co., Seattle, Wash.

Haskelite Manufacturing Corp., Grand Rapids, Mich.

Hastings, A. W., \& Co., Inc., Somerville, Mass.

Hawkins Lumber \& Warehouse Co., Boston, Mass.

Henrich Plywood Co., Inc., Buffalo, N. Y.

Higgins, J. E., Lumber Co., San Francisco, Calif.

Hill, Lyman, Hollywood, Calif.

Hodgdon, Charles, \& Son, San Gabriel, Calif.

Hodgson, E. F., Co., Boston, Mass.

Hoffmann Lumber Co., Pittsburgh, Pa.

Hogan Lumber Co., Oakland, Calif.

Holsman, Holsman, Klekamp \& Taylor, Chicago, Ill.

Houston Ready-Cut House Co., Houston, Tex.

Houston Sash \& Door Co., Houston, Tex.

Hunter Lumber Co., Chillicothe, Ill.

Hunting, R. D., Lumber Co., Cedar Rapids, Iowa.

Huss Lumber Co., Chicago, Ill.

Hyde-Murphy Co., Ridgway, $\mathrm{Pa}$

Indiana Lumber \&'Manufacturing Co., Inc., South Bend, Ind.

Interstate Sash \& Door Co., Canton, Ohio.

Iron City Sash \& Door Co., Pittsburgh, Pa.

Iron Mountain, City of, City Lumber Yard, Iron Mountain, Mich.

Jacksonville Sash \& Door Co., Jacksonville, Fla.

James Lumber Co., Boston, Mass.

Kaaz Woodwork Co., Inc., The, Leavenworth, Kans.

Keich \& O'Brien, Warren, Ohio.

Kellogg, Charles C., \& Sons Co., Utica, N. Y.

Kimball Lumber Co., Watertown, Mass.

Kneeland Bigelow Dist. Co., Bay City, Mich.

Lambert Luinber Co., Leavenworth, Kans.

Leidigh \& Havens Lumber Co., Salina, Kans.

Loeb, Laurence M., White Plains, N. Y.

Loetscher \& Burch Manufacturing Co., Des Moines, Iowa.

Logan Lumber Co., Tampa, Fla.

Loizeaux, J. D., Lumber Co., Plainfield, N. J.

Lomasney, J. F., \& Co., Los Angeles, Calif.

Long-Bell Lumber Co., The, Longvicw, Wash.

Lord \& Bushnell Lumber Co., Chicago, Ill

Los Angeles, City of, Los Angeles, Calif.

Lovatt, George I., Philadelphia, Pa.

Lowell, J. B., Inc., Worcester, Mass.
Lumber \& Millwork Co. of Philadelphia, The, Philadelphia, Pa.

Lundgren Dealers Supply, Inc., Tacoma, Wash.

Lyman-Hawkins Lumber Co., Akron, Ohio.

Lyon-Gray Lumber Co., Dallas, Tex.

Lyon Metal Products, Inc., Aurora, Ill.

Mahoney Sash \& Door Co., The, Canton, Ohio.

Mann \& Co., Hutchinson, Kans.

Markland, M. B., Contracting Co., Atlantic City, N.J.

Marquard Sash \& Door Manufacturing Co., The, Cleveland, Ohio.

Marr, Charles J., New Philadelphia, Ohio. (General support.)

Marsh \& Truman Lumber Co., Chicago, Ill.

Marshall-Wright Lumber Co., Inc., Ionia, Mich.

Martin, Edgar, Chicago, Ill.

Mason, George D., \& Co., Detroit, Mich.

Mason Lumber Co., Jacksonville, Fla.

Mauk Seattle Lumber Co., Seattle, Wash.

McGowin Lyons Hardware \& Supply Co., Mobile, Ala.

McGuinn, N. J., Lumber Co., Inc., Charlotte, N. C. McPhillips Manufacturing Co., Inc., Mobile, Ala. Mears, John H., Inc., Baltimore, Md.

Merritt Lumber Yards, Inc., Reading, Pa.

Metropolitan Millwork Co., Brooklyn, N. Y

Michigan Wholesalers, Inc., Jackson, Mich.

Midland Building Industries, Inc., Indianapolis, Ind.

Midwest Lumber Co., Dubuque, Iowa.

Miller Sash \& Door Co., Kalamazoo, Mich.

Miller \& Vrydagh, Terre Haute, Ind.

Mills Industries, Inc., Chicago, Ill.

Milwaukee Plywood Co., Milwaukee, Wis.

Minot Builders Supply Co., Minot, N. Dak.

Modecraft Co., Inc., The, Brooklyn, N. Y.

Moore \& Co., Le Mars, Iowa.

Moore Dry Dock Co., Oakland, Calif.

Mooser, William, San Francisco, Calif

Morrill \& Sturgeon Lumber Co., Portland, Oreg.

Morrison-Merrill \& Co., Salt Lake City, Utah.

Muhlenberg Bros., Reading, $\mathrm{Pa}$.

Mutual Millwork Co., Orlando, Fla.

Mutual Plywood Corp., Eureka, Calif.

National Plywood Co., Inc., New York, N. Y.

National Woodworks, Inc., Birmingham, Ala.

Neal-Blun Co., Savannah, Ga.

Neumann, William, \& Sons, Jersey City, N. J

New Century Homes, Inc., Clinton, Ind.

New York Wood Working Corp., Flushing, N. Y

Newton Lumber \& Manufacturing Co., The, Colorado Springs, Colo.

Niagara Plywood Co., Inc., Buffalo, N. Y.

Nicolai Plywood Co., Garibaldi. Oreg.

Nonbreakable Trunk Co., New York, N. Y.

Norwood Sash \& Door Manufacturing Co., Norwood, Ohio.

O \& N Lumber Co., Menomonic, W is.

Oakland Public Schools, Oakland, Calif.

Oettinger Lumber Co., Grecnsboro, N. C.

Officer, Gwynn, Lafayette, Calif.

Olson, E. C., Lumber Co., Spokane, Wash.

Omaha Hardwood Lumber Co, Omaha, Nebr.

Oregon Plywood Corp., Sweet Home, Oreg.

Oregon, State of, Board of Control, Purchasing Department, Salem, Oreg.

Owens-Parks Lumber Co., Los Angeles, Calif.

Pacific Mutual Door Co., Chicago, Ill., and Garwood, N.J.

Paducah Sash \& Door Co., Inc., Paducah, Ky.

Patten-Blinn Lumber Co. Los Angeles, Calif.

Patterson-Buck Hardwood Co., Dearborn, Mich.

Pease Woodwork Co., Cincinnati, Ohio.

Plywood Distributing Co., Chicago, Ill.

Portsmouth Lumber Corp., Portsmouth, Va.

Queensborough Lumber Co., Inc., Bayside, N. Y.

Quigley, J. R., Co., Gloucester City, N.J

Radford \& Sanders, Inc., Baltimore, Md.

Ramsey, A. H., \& Sons, Inc., Miami, Fla.

Remington Yards, Hibbing, N.inn.

Resnikoff, A braham, New York, N. Y.

Rhodes, Harry A., Rensselaer, N. Y.

Richardson-Phelps Lumber Co., Grinnell, Iowa.

Ripley-Hopping, Inc., Newark, N. J.

Roberts Sash \& Door Co., Chicago, Ill

Robinson, Fred J., Lumber Co., Detroit, Mich. 
Rock Island Millwork Co., St. Louis Division, St. Louis, Mo.

Rolfe Building Materials Co., New Brunswick, N.J. Rounds \& Palmer Co., Dallas, Tex., and Fort Worth, Tex.

Rounds \& Porter Co., Wichita and Dodge City, Kans.; Tulsa, Oklahoma City, and Altus, Okla. Royal Oak Wholesale Co., Royal Oak, Mich. Ruggles, Carlos, Lumber Co., Springfield, Mass.

Ruse \& Co., Baltimore, Md.

Russell, Crowell, Mullgardt \& Schwarz, St. Louis, Mo.

Rust Sash \& Door Co., Kansas Gity, Mo.

Sanders Bros. Manufacturing Co., Ottawa, Ill

Sandusky Lumber \& Supply Co., Sandusky, Ohio.

Sash, Door \& Glass Corp., Richmond, Va.

Scranton Plywood Co., Forty Fort, Pa.

Segelke \& Kohlhaus Co., La Crosse, Wis.

Semling-Menke Co., Inc., Merrill, Wis.

Shasta Plywood, Inc., Redding, Calif.

Shenk, Henry, Co., Erie, Pa.

Shutze \& Armistead, Atlanta, Ga.

Sierra Mill \& Lumber Co., Sacramento, Calif.

Simons, Inc., Minneapolis, Minn.

Simpson Logging Co., Seattle, Wash

Sirrine, J. E., Co., Greenville, S. C.

Sleeper, Harold R., New York, N. Y.

Snell Sash \& Door Co., St. Paul, Minn.

Snook-Veith Lumber Co., The, Cincinnati, Ohio

Southern Counties Gas Co. of California, Los Angeles, Calif.

Spokane Woodworking Co., Spokane, Wash.

Standard Store Equipment Co., Inc., Seattle, Wash.

Stanley, F. W., \& Co., Fort Worth, Tex.

Stanton, E. J., \& Son, Inc., Los Angeles, Calif.

Stcele \& Hibbard Lumber Co., St. Louis, Mo.

Stoetzel, Ralph, Chicago, Ill.

Strable Hardwood Co., Oakland, Calif.

Streeter, D. D., Brooklyn, N. Y.

Sutliffe, Milan R., Co., La Crosse, W is

Swan Lake Moulding Co., Klamath Falls, Oreg.

Sweet's Catalog Service, New York, N. Y. (Genera support).

Sweetwater Sash \& Door Co., Sweetwater, Tex.

Synvar Corp., Wilmington, Del.

Tacoma Plywood Corp., Tacoma, Wash.

Taylor, Ellery K., Haddonfield, N. J.

Taylor, Ellis Wing, Los Angeles, Calif.
Teachou
Mich.

Tennessee Glass Co., Nashville, Tenn.

Texas Technological College, Department of Architecture, Lubbock, Tex. (General support.)

Thew Shovel Co., The, Lorain, Ohio.

Timberline, Inc., Kansas City, Mo.

Trexler Lumber Co., Allentown, Pa

Underwood Coal \& Supply Co., Mobile, Ala.

Underwood Veneer Co., Wausau, Wis.

Van Arsdale-Harris Co., San Francisco, Calif.

Vaughan, Geo. C., \& Sons, Houston, Tex.

Velde Lumber Co., Pekin, Ill.

Vetter Manufacturing Co., Stevens Point, Wis.

Virginia Polytechnic Institute, Blacksburg, Va.

Vogel, Willis A., Toledo, Ohio.

Wanke Panel Co., Portland, Oreg.

Washington Woodworking Co., Washington, D. C.

Watertown Sash \& Door Co., Watertown, S. Dak.

Welch, Carroll E., Huntington, L. I., N. Y.

Welch Sash \& Door Co., Port Huron, Mich.

West Coast Veneer Co., Crescent City, Calif.

Western Door \& Sash Co., Oakland, Calif.

Western Electric Co., Inc., Kearny, N. J.

Western Hardwood Lumber Co., Los Angeles, Calif.

Whissel, L. N., Lumber Co., Inc., Buffalo, N. Y.

White Bros., San Francisco, Calif.

Wholesale Building Supply, Inc., Oakland, Calif.

Wholesale Distributing Co., Pittsbuigh, Pa.

Willatsen, Andrew, Seattle, Wash.

Winde, McCormick \& Chapin, Inc., Charlestown, Mass.

Winner Manufacturing Co., Inc., Trenton, N. J.

Wood Lumber Co., Birmingham, Ala.

Youngblood Lumber Co., Minneapolis, Minn

Y oungstown Plywood Co., Youngstown, Ohio.

Zimmerman, A. C., Los Angeles, Calif.

\section{UNITED STATES GOVERNMENT}

Agriculture, U. S. Department of, Division of Purchase, Sales and Traffic, Washington, D. C.

Federal Works Agency, Public Buildings Administration, Washington, D. C. (General support.)

Interior, U. S. Department of the, Bureau of Indian Affairs, Washington, D. C.

Veterans' Administration, Washington, D. C.

\section{COMMERCIAL STANDARDS}

CS No.

0-40. Commercial standards and their value to business (third edition).

1-42. Clinical thermometers (third edition).

2-30. Mopsticks.

3-40. Stoddard solvent (third edition).

4-29. Staple porcelain (all-clay) plumbing fixtures.

5-46. Pipe nipples; brass, copper, steel and wrought-iron (second edition).

6-31. Wrought-iron pipe nipples (second edition). Superseded by CS5-46.

7-29. Standard weight malleable iron or steel screwed unions.

8-41. Gage blanks (third edition)

9-33. Builders' template hardware (second edition).

10-29. Brass pipe nipples. Superseded by CS5-46.

11-41. Moisture regains of cotton yarns (second edition).

12-48. Fuel oils (sixth edition)

13-44. Dress patterns (fourth edition).

14-43. Boys' button-on waists, shirts, junior and sport shirts (made from woven fabrics) (third edition).

15-46. Men's pajama sizes (made from woven fabrics) (third edition).

16-29. Wallpaper.

17-47. Diamond core drill fittings (fourth edition).

18-29. Hickory golf shafts.

19-32. Foundry patterns of wood (second edition).

20-47. Staple vitreous china plumbing fixtures (fourth edition)

21-39. Interchangeable ground-glass joints, stopcocks, and stoppers (fourth edition).
CS No.

22-40. Builders' hardware (nontemplate) (second edition)

23-30. Feldspar.

24-43. Screw threads and tap-drill sizes.

25-30. Special screw threads. Superseded by CS24-43.

26-30. Aromatic red cedar closet lining.

27-36. Mirrors (second edition).

28-46. Cotton fabric tents, tarpaulins and covers (second edition).

29-31. Staple seats for water-closet bowls.

30-31. Colors for sanitary ware. (Withdrawn as commercial standard, March 15, 1948.)

31-38. Wood shingles (fourth edition)

$32-31$. Cotton cloth for rubber and pyroxylin coating.

33-43. Knit underwear (exclusive of rayon) (second edition).

34-31. Bag, case, and strap leather

35-47. Hardwood plywood (third edition)

36-33. Fourdrinier wire cloth (second edition).

37-31. Steel bone plates and screws.

38-32. Hospital rubber sheeting.

39-37. Wool and part wool blankets (second edition). (Withdrawn as commercial standard, July 14, 1941.)

40-32. Surgeons' rubber gloves.

41-32. Surgeons' latex gloves.

42-43. Structural fiber insulating board (third edition)

43-32. Grading of sulphonated oils.

44-32. A pple wraps.

45-48. Douglas fir plywood (eighth edition). 
CS No.

46-40. Hosiery lengths and sizes (third edition).

47-34. Marking of gold-filled and rolled-gold-plate articles other than watch cases.

48-40. Domestic burners for Pennsylvania anthracite (underfeed type) (second edition).

49-34. Chip board, laminated chip board, and miscellaneous boards for bookbinding purposes.

50-34. Binders board for bookbinding and other purposes.

51-35. Marking articles made of silver in combination with gold.

52-35. Mohair pile fabries (100-percent mohair plain velvet, 100-percent mohair plain frieze, and 50 -percent mohair plain frieze).

53-35. Colors and finishes for cast stone.

54-35. Mattresses for hospitals.

55-35. Mattresses for institutions.

56-49. Oak flooring (third edition).

57-40. Book cloths, buckrams, and impregnated fabrics for bookbinding purposes except library bindings (second edition).

58-36. Woven elastic fabrics for use in overalls (overall elastic webbing).

59-44. Textiles-testing and reporting (fourth edition).

60-48. Hardwood dimension lumber (second edition).

61-37. Wood-slat venetian blinds.

$62-38$. Colors for kitchen accessories.

63-38. Colors for bathroom accessories.

64-37. Walnut veneers.

65-43. Methods of analysis and of reporting flber

- composition of textile products (second edition).

66-38. Marking of articles made wholly or in part of platinum.

67-38. Marking articles made of karat gold.

68-38. Liquid hypochlorite disinfectant, deodorant, and germicide.

69-38. Pine oil disinfectant.

70-41. Phenolic disinfectant (emulsifying type) (second edition) (published with CS71-41)

71-41. Phenolic disinfectant (soluble type) (second edition) (published with CS70-41).

72-38. Household insecticide (liquid spray type).

73-48. Old growth Douglas fir, Sitka spruce and Western hemlock standard stock doors (fourth edition).

74-39. Solid hardwood wall paneling.

75-42. Automatic mechanical draft oil burners designed for domestic installations (second edition).

76-39. Hardwood interior trim and molding.

77-48. Enameled cast iron plumbing fixtures (second edition).

78-40. Ground-and-polished lenses for sun glasses (second edition) (published with CS79-40).

79-40. Blown, drawn, and dropped lenses for sun glasses (second edition) (published with CS78-40).

80-41. Electric direction signal systems other than semaphore type for commercial and other vehicles subject to special motor vehicle laws (after market).

81-41. Adverse-weather lamps for vehicles (after market).

82-41. Inner-controlled spotlamps for vehicles (after market).

83-41. Clearance, marker, and identification lamps for vehicles (after market).

84-41. Electric tail lamps for vehicles (after market)

85-41. Electric license-plate lamps for vehicles (after market).

$86-41$. Electric stop lamps for vehicles (after market).

87-41. Red electric warning lanterns.

88-41. Liquid burning flares.

89-40. Hardwood stair treads and risers.

90- . (Reserved for power shovels and cranes.)

91-41. Factory-fitted Douglas fir entrance doors.

92-41. Cedar, cypress, and redwood tank stock lumber.
CS No.

93-41. Portable electric drills (exclusive of high frequency).

94-41. Calking lead.

95-41. Lead pipe.

96-41. Lead traps and bends.

97-42. Electric supplementary driving and passing lamps for vehicles (after market).

98-42. Artists' oil paints.

99-42. Gas floor furnaces-gravity circulating type.

100-47. Porcelain-enameled steel utensils (third edition).

101-43. Flue-connected oil-burning space heaters equipped with vaporizing pot-type burners 102- (Reserved for Diesel and fuel-oil engines.)

103-48. Rayon jacquard velour (with or without other decorative yarn) (second edition).

104-46. Warm-air furnaces equipped with vaporizing pot-type oil burners (second edition).

105-48. Mineral wool insulation for low temperatures (second edition).

106-44. Boys' pajama sizes (woven fabrics) (second edition).

107-45. Commercial electric-refrigeration condensing units (second edition). (Withdrawn as commercial standard September 4, 1947.)

108-43. Treading automobile and truck tires.

109-44. Solid-fuel-burning forced-air furnaces.

110-43. Tire r epairs-vulcanized (passenger, truck, and bus tires).

111-43. Earthenware (vitreous-glazed) plumbing fixtures.

112-43. Homogeneous fiber wallboard.

113-44. Oil-burning floor furnaces, equipped with vaporizing pot-type burners.

114-43. Hospital sheeting for mattress protection.

115-44. Porcelain-enameled tanks for domestic use.

116-44. Bituminized-fibre drain and sewer pipe.

117-44. Mineral wool; blankets, blocks, insulating cement, and pipe insulation for heated industrial equipment.

118-44. Marking of jewelry and novelties of silver.

(E) 119-45. ${ }^{1}$ Dial indicators (for linear measurements).

120-48. Standard stock ponderosa pine doors (third edition).

121-45. Women's slip sizes (woven fabrics).

122-45. Western hemlock plywood.

123-45. Grading of diamond powder.

(E)124-45.1 Master disks.

125-47. Prefabricated homes (second edition).

126-45. Tank-mounted air compressors.

$127-45$. Self-contained mechanically refrigerated drinking water coolers.

128-45. Men's sport shirt sizes-woven fabrics (other than those marked with regular neckband sizes).

129-47. Materials for safety wearing apparel (second edition).

130-46. Color materials for art education in schools.

131-46. Industrial mineral wool products, all typestesting and reporting.

132-46. Hardware cloth.

133-46. Woven wire netting.

134-46. Cast aluminum cooking utensils (metal composition).

135-46. Men's shirt sizes (exclusive of work shirts).

136-46. Blankets for hospitals (wool, and wool and cotton).

137-46. Size measurements for men's and boys' shorts (woven fabrics)

138-47. Insect wire screening.

139-47. Work gloves.

140-47. Testing and rating convectors.

141-47. Sine bars, blocks, plates, and fixtures.

142-47. Automotive lifts.

143-47. Standard strength and extra strength perforated clay pipe.

144-47. Formed metal porcelain enameled sanitary ware.

145-47. Testing and rating hand-fired hot-water-supply boilers.

146-47. Gowns for hospital patients.

1 Where "(E)" precedes the CS number, it indicates an emergency commercial standard, drafted under war conditions with a view toward early revision. 
CS No.

147-47. Colors for molded urea plastics.

148-48. Men's circular flat and rib knit rayon underwear.

149-48. Utility type house-dress sizes.

150-48. Hot-rolled rail steel bars (produced from Tee-section rails)

151-48. Body measurements for the sizing of apparel for infants, babies, toddlers, and children (for the knit-underwear industry).
CS No.

152-48. Copper naphthenate wood preservative.

153-48. Body measurements for the sizing of appare for girls (for the knit-underwear industry) 154- . (Reserved for wire rope.)

155-49. Body measurements for the sizing of appare for boys (for the knit-underwear industry). $156-49$. Colors for polystyrene plasties.

157-49. Ponderosa pine and sugar pine plywood.

158-49. Model forms for girls' apparel.

NoticE.-Those interested in commercial standards with a view toward accepting them as a basis of everyday practice may secure copies of the above standards, while the supply lasts, by addressing the Commodity Standards Division, National Bureau of Standards, Washington 25, D. C. 
